\title{
Review
}

\section{Recognition and repair of DNA-cisplatin adducts ${ }^{\star}$}

\author{
Katarzyna Woźniak and Janusz Błasiak ${ }^{\bowtie}$
}

Department of Molecular Genetics, University of Łódż, S. Banacha 12/16, 90-237 Łódż, Poland

Received: 27 February, 2002; revised: 03 June, 2002; accepted: 19 July, 2002

Key words: cisplatin, cis-diamminedichloroplatinum, DNA damage, DNA repair, DNA adducts,

DNA-protein crosslinks

\begin{abstract}
Anticancer activity of cisplatin (cis-diamminedichloroplatinum) is believed to result from its interaction with DNA. The drug reacts with nucleophilic sites in DNA forming monoadducts as well as intra- and interstrand crosslinks. DNA-cisplatin adducts are specifically recognized by several proteins. They can be divided into two classes. One constitutes proteins which recognize DNA damage as an initial step of the nucleotide excision and mismatch repair pathways. The other class contains proteins stabilizing cellular DNA-protein and protein-protein complexes, including non-histone proteins from the HMG (high-mobility-group) family. They specifically recognize 1,2-interstrand $d(G p G)$ and $d(A p G)$ crosslinks of DNA-cisplatin adducts and inhibit their repair. Many HMG-domain proteins can function as transcription factors, e.g. UBF, an RNA polymerase I transcription factor, the mammalian testis-determining factor SRY and the human mitochondrial transcription factor mtTFA. Moreover, it seems that some proteins, which probably recognize DNA-cisplatin adducts non-specifically, e.g. actin and other nuclear matrix proteins, can disturb the structural and functional organization of the nucleus and whole cell. The formation of complexes between DNA and proteins in the presence of cisplatin and the changes in the cell architecture may account for the drug cytotoxicity.
\end{abstract}

Cisplatin (cis-diamminedichloroplatinum) (Fig. 1) is one of the most effective chemotherapeutic agents for cancer treatment (Loehrer \& Einhorn, 1984). The biological activity of cisplatin was discovered in the early sixties (Rosenberg et al., 1965; Rosenberg et al., 1967; Brown et al., 1994). The drug was approved in 1978 for clinical treatment. It is generally accepted that the cytotoxic activity of the drug results from its interactions with

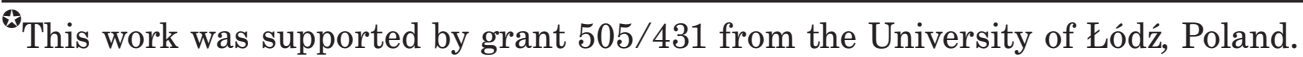

${ }^{凶}$ Please send all correspondence to Janusz Blasiak at the above address: phone (48 42) 635 4334, fax (48 42) 635 4484, e-mail: januszb@biol.uni.lodz.pl
}

Abbreviations: AAG, 3-methyladenine-DNA glycosylase; HMG, high-mobility-group; MMR, mismatch repair; UBF, RNA-polymerase I transcription factor. 
<smiles>N[Pb](N)(Cl)Cl</smiles>

cisplatin<smiles>N[PH](N)(N)OCC(=O)O</smiles>

nedaplatin<smiles>N[PH](N)(N)OC(=O)C1(C(=O)O)CCC1</smiles>

carboplatin<smiles>CC1OP2([NH3+])(NCC3CCC3CN2)OC1=O</smiles>

lobaplatin<smiles>N[P+]1(N)O[Se](=O)O1</smiles>

Se-Pt conjugate

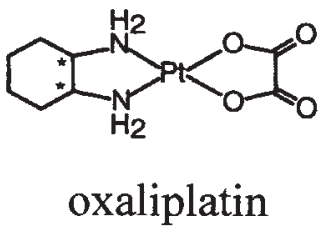<smiles></smiles>

ZD0473<smiles></smiles>

oxoplatin

Figure 1. Structure of cisplatin and its analogues.

DNA (Fig. 2). DNA-platinum covalent adducts inhibit fundamental cellular processes, including replication, transcription, translation and DNA repair (Corda et al., 1991; Comess et al., 1992; Szymkowski et al., 1992; Sato \& Rosenberg, 1993; Vichi et al., 1997; Heminger et al., 1997; Jordan \& CarmoFonseca, 1998; Suo et al., 1999). The trans isomer of cisplatin - trans-diamminedichloroplatinum (transplatin) is clinically inactive although it can also induce DNA damage. Many nuclear proteins can bind to cis- or transplatin-modified DNA. Some of them specifically recognize the major DNA adducts induced by cisplatin. It is thought that these specific DNA-protein interactions are responsible for the anticancer activity of cisplatin.

\section{STRUCTURAL ALTERATIONS OF DNA EVOKED BY CISPLATIN}

The N7 atoms of guanine and adenine are the main binding sites for platinum complexes in double-stranded DNA. The interac- tion between cisplatin and DNA can result in mono- and bifunctional adducts, as well as DNA-protein crosslinks. The bifunctional adducts, which can take the form of intra- or interstrand crosslinks, may cause major local distortions of DNA structure, involving both bending and unwinding of the double helix (Table 1). The intrastrand crosslinks cis-Pt( $\left.\mathrm{NH}_{3}\right)_{2}$-d(GpG) $(60-65 \%$ of the total) and cis-Pt( $\left(\mathrm{NH}_{3}\right)_{2}$-d(ApG) (22-30\%) are the most abundant products of the interaction (Fichtinger-Schepman et al., 1985). These crosslinks, which comprise $90 \%$ of the DNA-cisplatin adducts, bend the helix by $34^{\circ}$ towards its major groove and unwind it by $13^{\circ}$ (Bellon et al., 1991). Interstrand crosslinks represent a small amount of the total cisplatin lesions but several studies have suggested that they could also be responsible for the cytotoxicity of the drug. The distortions induced by these crosslinks exhibit unprecedented features such as location of the platinum residue in the minor groove, extrusion of the cytosines of the crosslinked $d(\mathrm{GpC}) d(\mathrm{GpC})$ site, bending of the helix axis towards the minor groove and 
1,2-d(GpG) intrastrand crosslink

$1,2-\mathrm{d}(\mathrm{ApG})$ intrastrand crosslink

1,3-d(GpTpG) intrastrand crosslink

$\mathrm{d}(\mathrm{GpC}) \mathrm{d}(\mathrm{GpC})$ interstrand crosslink
TCTAGGCCTTCT AGATCCGGAAGA

\author{
TCTTAGTTCTCT \\ AGAATCAAGAGA
}

\section{TCTGTGCACTCT} AGACACGTGAGA

\section{TCCTTGCTCTCC AGGAACGAGAGG}

Figure 2. Schematic representation of cisplatin adducts. The platinated nucleosides are underlined.

large DNA unwinding (Table 1) (Malinge et al., 1999).

\section{INCREASED EFFICACY OF DNA REPAIR MAY UNDERLIE CELLULAR RESISTANCE TO CISPLATIN}

A major clinical limitation of the use of cisplatin is the intrinsic or acquired resistance to the drug. Postulated mechanisms of resistance to cisplatin include reduced drug uptake or decreased drug accumulation, increased levels of intracellular thiols and metallothioneins and increased level of repair of DNA-cisplatin adducts (Parker et al., 1991; Chu, 1994; Chen et al., 1995). More recently, additional pathways have been characterized indicating that altered expression of oncogenes that subsequently limit the formation of DNA-cisplatin adducts and activate antiapoptotic pathways may also contribute to the resistance phenotype. It is suggested that expression of ras oncogenes can confer resistance to cisplatin by reducing drug uptake and increasing DNA repair (Dempke et al., 2000; Niedner et al., 2001). We have recently shown that oncogenic fusion tyrosine kinases (FTKs)

Table 1. Structural alterations in double-stranded DNA caused by cisplatin

\begin{tabular}{lccl}
\hline \multirow{2}{*}{ DNA-cisplatin adduct } & \multicolumn{2}{c}{ DNA } & Reference \\
\cline { 2 - 3 } Intrastrand crosslinks & unwinding angle & bending angle & \\
- GpG & $13^{\mathrm{a}}$ & $35^{\mathrm{a}}$ & (Bellon et al., 1991) \\
& & $26^{\mathrm{b}}$ & (Tahakara et al., 1996) \\
$-\mathrm{GpA}$ & $13^{\mathrm{a}}$ & $35^{\mathrm{a}}$ & (Bellon et al., 1991) \\
$-\mathrm{GpTpG}$ & $23^{\mathrm{a}}$ & $33^{\mathrm{a}}$ & (Bellon et al., 1991) \\
Interstrand crosslinks & & & \\
$-\mathrm{GpG}$ & $70^{\mathrm{b}}$ & $47^{\mathrm{b}}$ & (Coste et al., 1999) \\
& $79^{\mathrm{a}}$ & $45^{\mathrm{a}}$ & (Malinge et al., 1994) \\
\hline
\end{tabular}

${ }^{\mathrm{a}}$ Determined by gel electrophoresis, ${ }^{\mathrm{b}}$ determined by crystallography. 
such as BCR/ABL, TEL/ABL, TEL/JAK2, TEL/PDGF $\beta$ R, TEL/TRKC(L) and NPM/ ALK may stimulate the repair of cisplatin damaged DNA by a mechanism dependent on the RAD51 protein and it this way contribute to the cellular resistance to the drug (Slupianek et al., 2002).

The repair of cisplatin adducts occurs primarily by the nucleotide excision repair pathway (NER) (Zamble et al., 1996). Cell lines from patients with XP (xeroderma pigmentosum) are highly sensitive to cisplatin, even 4-fold more sensitive than normal cells (Fraval et al., 1978; Dijt et al., 1988). NER in human cells involves recognition of damage by XPA in complex with the RPA protein, incision by the specific endonucleases XPG at the $3^{\prime}$ side of the lesion and ERCC1/XPF at the 5' side and repair DNA synthesis mediated by a PCNA-dependent DNA polymerase (Aboussekhra \& Wood, 1994; Wood, 1996). The more distorting 1,3-intrastrand d(GpTpG)-cisplatin crosslink is repaired about $15-20$-fold more effectively by human whole cell extract than the less distorting 1,2-intrastrand $d(\mathrm{GpG})$ cisplatin crosslink (Moggs et al., 1997). The poorer repair of 1,2 crosslinks in comparison with the 1,3 crosslinks is a consequence of different structural alterations of the DNA helix and a repair-shielding mechanism mediated by HMG (high-mobility-group)-domain proteins.

Several earlier studies showed that cisplatin-resistant cell lines exhibited overproduction of nuclear proteins preferentially binding cisplatin-modified DNA (Chao et al., 1991; Nishio et al., 1994). Initially, it was suggested that the binding of these proteins might assist in damage recognition and thus promote repair. It is now accepted that specific recognition of DNA-cisplatin adducts by nuclear proteins, especially from the HMG-domain family, inhibits nucleotide excision repair and may enhance cisplatin sensitivity (Huang et al., 1994; Zamble et al., 1996; Trimmer et al., 1998; Arioka et al., 1999; Trimmer \& Essigmannn, 1999; Jordan \&
Carmo-Fonseca, 2000). It was reported that a yeast strain with an inactivated IXR 1 gene was twice as resistant to cisplatin as its parental strain (Brown et al., 1993). This result strongly indicates that Ixr1 - a protein containing two HMG domains - can inhibit the repair of DNA-cisplatin adducts and may confer the drug sensitivity.

An increased expression of the human NER repair genes $X P A$ and $E R C C 1$ was reported in tumour tissue of some patients with malignant ovarian cancer who did not respond to platinum-based chemotherapy (Dabholkar et al., 1994; Yu et al., 1996; Li et al., 2000). It was also shown that ERCC1 mRNA level was correlated with clinical resistance to cisplatinbased chemotherapy in human gastric cancer (Metzger et al., 1998). While transfection of an XPA-expressing vector into XPA-deficient cell lines could restore NER activity, overexpression of the same plasmid in repair-proficient cell lines did not appear to have any substantial effect on the activity levels (Cleaver et al., 1995). In addition, transfection of ERCC1 restored repair of interstrand crosslinks in cell lines that were deficient in this protein, while overexpression of ERCC1 appeared to inhibit repair of these crosslinks (Larminat \& Bohr, 1994; Chaney \& Sancar, 1996). Therefore, there is no clear evidence of overexpression of the NER genes in resistant cell lines or in resistant tumours. Further studies are needed to elucidate the molecular basis of repair-dependent resistance to cisplatin.

It was found that human 3-methyladenine-DNA glycosylase (AAG), a protein involved in the first step of base excision repair, can bind tightly to cisplatin adducts (Kartalou et al., 2000). It is proposed that analogous to "transcription factor hijacking" cisplatin adducts could titrate human AAG away from lesions such as 3-methyladenine and 3-methylguanine, leading to enhanced toxicity because of the inhibition of repair of these lesions by AAG. On the other hand, it is also possible that AAG binds to cisplatin adducts and, be- 
cause it cannot excise them, it conveys the adducts to the nucleotide excision repair pathway through the interaction of AAG with the hHR23 proteins (Miao et al., 2000; Kartalou \& Essigmann, 2001). Thus the interaction between AAG and DNA-cisplatin adducts can increase the efficiency of DNA repair and, in the case of overexpression of this protein, could lead to cisplatin resistance.

In normal human cells, mispaired bases or short insertions/deletions in DNA are recognized by complex proteins of the mismatch repair system (MMR): hMutS $\alpha$ (heterodimer of hMSH2 and hMSH6) or hMutS $\beta$ (heterodimer of hMSH2 and hMSH3). The hMutS complexes are thought to recruit the hMutL $\alpha$ heterodimer consisting of the hMLH1 and PMS2 proteins. The hMutS $\alpha$ complex and hMSH2 can recognize DNA-cisplatin adducts (Fink et al., 1996; Duckett et al., 1996; Modrich, 1997). A direct comparison among several mismatched platinated DNA molecules showed that the hMutS $\alpha$ complex recognized duplex DNA containing a 1,2-intrastrand $\mathrm{d}(\mathrm{GpG})$-cisplatin crosslink with a much higher affinity when the non-damaged DNA strand contained a mispaired thymine opposite the 3 ' platinated guanine (Yamada et al., 1997). This crosslink was also repaired more effectively by nucleotide excision repair when placed opposite one or two non-complementary thymine residues (Moggs et al., 1997).

Loss of MMR was reported to be associated with low-level resistance to cisplatin (Anthoney et al., 1996; Aebi et al., 1996; Vaisman et $a l$., 1998). These observations indicated defects in hMLH1 or hMSH6, but not in the hMSH3 MMR protein (Vaisman et al., 1998). It was postulated that deficiency in the hMutS $\alpha$ and hMutL $\alpha$ complexes affected cisplatin resistance by facilitating replicative bypass of cisplatin adducts. In cisplatin sensitive cells DNA-cisplatin adducts are bypassed during replication, then the adducts are bound by the hMutS $\alpha / \mathrm{hMutL} \alpha$ complex this would most likely result in removal of the newly synthesized strand of DNA and retention of the parental strand containing the platinum adducts, because mismatch repair is selective for nascent DNA (Vaisman et al., 1998). Therefore, the damage remains unrepaired. Continuous operation of these futile cycles of resynthesis and mismatch repair is likely to generate persistent gaps or strand breaks, which may lead to cell death. In cells with defective mismatch repair, lack of one of the components of the hMutS $\alpha /$ hMutL $\alpha$ complex may allow completion of DNA replication and evoke some tolerance to the drug. Therefore, cells with an inactive mismatch repair system can better tolerate DNA adducts in the short term, but they display increased rates of other DNA damages leading to mutations (Hoffmann et al., 1996; Vaisman et al., 1998; Lin et al., 1999).

\section{RECOGNITION OF DNA-CISPLATIN ADDUCTS BY HMG-DOMAIN PROTEINS}

The HMG-domain proteins constitute the largest and most extensively characterized group of non-histone chromosomal proteins (Bustin \& Reeves, 1996). They can bind to specific structures in DNA or in chromatin with little or no specificity for the target DNA sequence.

HMG-domains are basic domains of 80 amino acids containing three $\alpha$-helical regions and well-conserved hydrophobic amino acids within their sequences (Grosschedl et al., 1994). Two families of HMG proteins have been reported. The first consists of proteins containing two or more HMG domains, it includes the HMG1 and HMG2 proteins, the nucleolar RNA polymerase I transcription factor UBF and the mitochondrial transcription factor mtTF. In the second family there are proteins containing single HMG domain, such as tissue-specific transcription factors, e.g. the mammalian testis-determining factor SRY and the lymphoid enhancer-binding factor LEF-1. 
Several types of HMG proteins, including HMG1, HMG2 and UBF bind to DNA-cisplatin adducts with high affinity and specificity (Pil \& Lippard, 1992; Hughes et al., 1992; Chow et al., 1995; Locker et al., 1995; McA'Nulty et al., 1996; Turchi et al., 1996; Farid et al., 1996; Ohndorf et al., 1997; Trimmer et al., 1998, Zlatanova et al., 1998; Ohndorf et al., 1999; Turchi et al., 1999; Kartalou \& Essigmann, 2001). These proteins recognize 1,2-intrastrand crosslinks that comprise the majority of adducts formed by cisplatin in vivo. Domain A of the structure-specific HMG protein HMG1 was reported to bind to the widened minor groove of a 16-base-pair DNA duplex containing a site-specific cis-Pt( $\left(\mathrm{NH}_{3}\right)_{2}$ - $\mathrm{d}(\mathrm{GpG})$ adduct (Ohndorf et al., 1999). DNA was strongly kinked at the hydrophobic notch created at the DNA-platinum crosslink and the protein binding extended exclusively at the 3 ' side of the platinated strand (Fig. 3).

To explain the observed effects it was suggested that DNA-cisplatin adducts might act as molecular decoys in cells, titrating away HMG-domain proteins from their natural binding sites and thereby disrupting their function. It was also suggested that after the drug exposure, HMG1 and HMG2 proteins migrated from the cytosol into the nucleus, where they bound to DNA-cisplatin adducts (Chao et al., 1996). It was also observed in this study that UBF distribution changed from its normal, well-defined location, associated with the nucleoli, to a more dispersed pattern of nuclear staining. UBF, being an RNA polymerase I transcription factor, plays an important role in the efficient transcription of rRNA genes and binds to rRNA promoter sequences (Jantzen et al., 1990). It could preferentially bind to DNA-cisplatin adducts in rRNA genes due to its natural close proximity to this region. Another hypothesis supposes that DNA-cisplatin adducts selectively compete with the rRNA promoter for UBF binding resulting in "cisplatin-mediated transcription factor hijacking” which reduces rRNA synthe- sis in growing cells (Treiber et al., 1994). It was shown that cisplatin blocks synthesis of rRNA (Jordan \& Carmo-Fonseca, 1998). Besides the redistribution of UBF in the nucleoli of human cells, redistribution of the major components of the rRNA transcription machinery, TBP, TAF ${ }_{I S}$ and RNA polymerase I, was also observed (Chao et al., 1996).

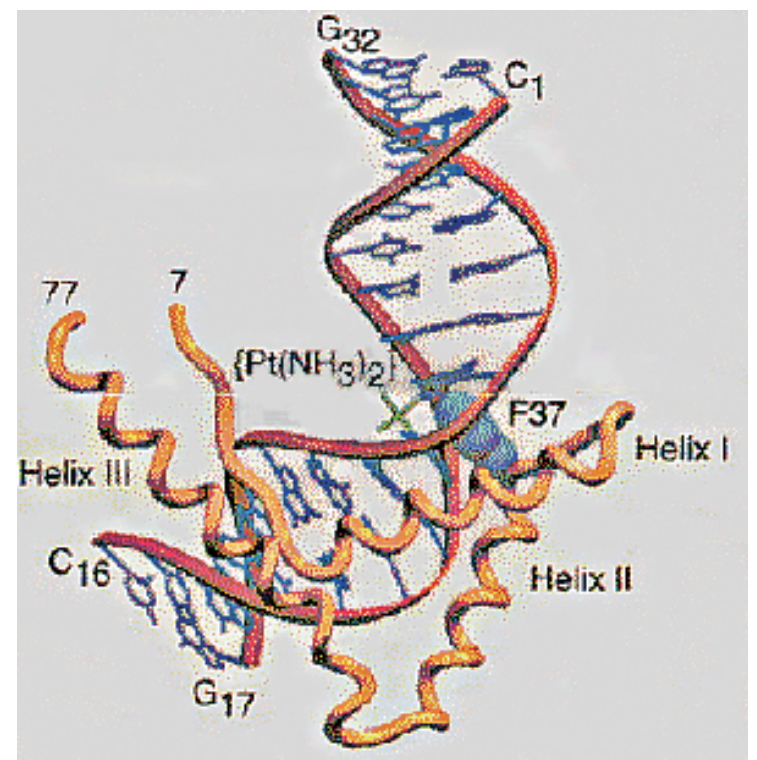

Figure 3. Structure of the complex between the non-sequence-specific domain A of HMG1 and cisplatin-modified DNA.

The protein backbone is shown in yellow, the intercalating Phe37 residue as van der Waals spheres and DNA in red and blue with the cis-[Pt( $\left.\mathrm{NH}_{3}\right)_{2}\{\mathrm{~d}(\mathrm{GpG})-\mathrm{N} 7-$ $\left.\left.\left(\mathrm{G}_{8}\right)-\mathrm{N} 7\left(\mathrm{G}_{9}\right)\right\}\right]$ intrastrand adduct in green. Numbers indicate the first ( $\mathrm{N}$ terminus) and last (C terminus) ordered residues in the crystal structure (reprinted with permission from Ohndorf U-M, Rould MA, He Q, Pabo CO, Lippard SJ. (1999) Nature (London) 399: 708-12).

The HMG-domain protein-mediated cytotoxicity of cisplatin may be explained as a result of the recognition of DNA-cisplatin adducts by tissue-specific HMG proteins. Cisplatin is very effective in the treatment of testicular cancer, with over $70 \%$ of patients cured (Loehrer \& Einhorn, 1984; Brown et al., 1994). Several HMG-domain proteins are specifically expressed in the testis and could potentially contribute to the cisplatin sensitivity of testicular tumours. One of these proteins is human testis-determining factor hSRY. The 
ability of hSRY to interact with bent DNA structures and to bend linear DNA has suggested that the protein may modulate transcription by acting architecturally in the assembly of a nucleoprotein complex (Pontiggia et al., 1994). It was shown that full length hSRY bound to the major 1,2-d(GpG) cisplatin adduct with a $K_{\mathrm{d}(\mathrm{app})}$ of $120 \pm 10 \mathrm{nM}$ and exhibited a 20 -fold specificity over unmodified DNA (Trimmer et al., 1998). It was also demonstrated in that study that the HMG-domain of hSRY was sufficient for this interaction. The hSRY-HMG domain recognized the 1,2-d(GpG) intrastrand crosslink with higher affinity but with lower specificity than the full-length protein. The affinities of full-length hSRY and the hSRY-HMG domain for a single DNA adduct were comparable to those for the putative target sequence AACAAAG. Other results suggest that DNA-cisplatin adducts may compete with specific DNA sequences in vivo for the binding of hSRY (Trimmer et al., 1998). Recognition of 1,2-d(GpG) intrastrand crosslink of cisplatin by the murine testis-specific HMG-domain protein (tsHMG) was also described (Ohndorf et al., 1997). These results show that the specificity of tsHMG for platinated DNA is much higher than that observed for other HMG-domain proteins, including Ixr 1 and hUBF (Treiber et al., 1994; McA'Nulty et al., 1996).

The competition between DNA-cisplatin adducts and structure- and/or sequence-specific sites in DNA in the recognition by testis-specific HMG-domain proteins can, at least in part, explain the high sensitivity of testicular tumours to cisplatin. This competition can reduce transcription of genes important for testis cell viability and finally cause the cell death.

\section{HMG PROTEINS AND EXCISION REPAIR OF DNA-CISPLATIN ADDUCTS}

It was suggested that DNA-HMG-domain protein complexes can protect cisplatin ad- ducts against repair. Therefore, HMG proteins can sensitize cells to cisplatin by a repair-shielding mechanism (Huang et al., 1994; Zamble et al., 1996; Trimmer et al., 1998; Arioka et al., 1999). It was shown that HMG proteins, HMG1 and h-mtTFA, specifically inhibited repair of the 1,2-intrastrand $d(\mathrm{GpG})$ crosslink, but the removal of the 1,3-d(GpTpG) crosslink was not inhibited (Huang et $a l .$, 1994). Similar experiments checking the ability of another HMG protein, to inhibit the repair of DNA-cisplatin adducts were performed with tsHMG. This protein bound specifically to the 1,2-d(GpG) intrastrand adduct, but not to the 1,3-d(GpTpG) crosslink (Zamble et al., 1996). Therefore, it could inhibit repair of the 1,2-intrastrand, but not the 1,3-intrastrand crosslink. Furthermore, human SRY selectively inhibited repair of the 1,2-d(GpG) adduct in an in vitro excision repair assay (Trimmer et al., 1998).

Many studies are directed to understand why cisplatin is more effective in treating testicular tumours than tumours of other tissues. Several HMG-domain proteins are specifically expressed in the testis and they can participate in the cisplatin reactivity toward testicular tumours. Testis-specific HMG-domain proteins bind to the most abundant cisplatin adducts and protect then from nucleotide excision repair.

\section{NUCLEAR ACTIN CAN BIND TO DNA-CISPLATIN ADDUCTS}

The nuclear matrix contains sequence-specific DNA binding activities of several transcription factors (van Wijnen et al., 1993; Nardozza et al., 1996). DNA loop anchorage sites are localised in the enhancer regions or intronic sequences of several genes within the nuclear matrix. These sequences have been termed matrix-associated regions (MARs) or scaffold associated regions (SARs) and usually are approximately 200 base pairs in length, are A-T-rich and contain topoiso- 
merase cleavage sites, polyadenylation signals and telomeric DNA sequences (Roberge \& Gasser, 1992; de Lange, 1992).

Actin was found to be the major protein crosslinked to the DNA of Chinese hamster ovary cells treated with cisplatin (Miller et al., 1991). Its aggregates colocalize with transcription sites (Clubb \& Locke, 1998; Nguyen et al., 1998). More than $90 \%$ of mRNA precursor molecules remain tightly bound to the nuclear matrix during the preparation of matrix from leukemia cells. This interaction relies on actin, since mRNA precursors can be extracted under conditions promoting filamentous actin depolymerization (Nakayasu \& Ueda, 1985). Small nuclear ribonucleoproteins (snRNP) have also been shown to be associated with actin in the nuclear matrix (Sahlas et al., 1993). The involvement of actin in DNA-protein crosslinks induced by cisplatin can disturb the nuclear metabolism and the spatial organization of chromatin. On the other hand cisplatin, at low concentration, can affect the polymerization of G-actin and induce the depolymerization and crosslinking of the actin polymer at a higher concentration (Zeng et al., 1996). Cisplatin can alter the natural interactions between DNA and actin or actin and other proteins leading finally to the cell death.

The proteins participating in DNA-protein crosslinks by cisplatin can be found among nuclear matrix proteins (Oliński et al., 1987; Miller et al., 1991; Ferraro et al., 1992; Woźniak \& Walter, 2002). The presence of nuclear proteins of 50 and $53 \mathrm{kDa}$, in addition to actin, crosslinked to DNA following exposure to cisplatin was shown (Miller et al., 1991). These proteins are abundant in the nuclear matrix fraction. A comparison of the various electrophoretic patterns of proteins crosslinked to DNA allowed the detection of several similarities between various animal species (Ferraro et al., 1992). It was also shown that nuclear proteins of $28,30,34.5,45$ and 120 $\mathrm{kDa}$ were crosslinked with DNA in human lymphocytes after incubation with cisplatin. The polypeptide of $34.5 \mathrm{kDa}$ crosslinked to
DNA after 2-h incubation with cisplatin (Woźniak \& Walter, 2002). When Novikoff hepatoma-bearing rats were given injections of a therapeutic dose of cisplatin, DNA-protein crosslinks could be detected by using antisera to dehistonized chromatin, nuclear matrix and cytoskeletal preparation. The principal proteins crosslinked to DNA by cis- and transplatin were Novikoff hepatoma cytokeratins (Oliński et al., 1987).

The human telomere sequences consisting of several thousand nucleotides of the repeating sequence (TTAGGG) $)_{\mathrm{n}}$ are attached to the nuclear matrix (de Lange, 1992). The G-rich sequence of the telomeres is potentially a good target for cisplatin binding. It was demonstrated that treatment of HeLa cells with cisplatin at low doses resulted in degradation and shortening of telomeres (Ishibashi \& Lippard, 1998). Several studies indicated that cisplatin could also interfere with telomerase activity (Burger et al., 1997; Asai et al., 1998). Therefore, cisplatin can affect both telomeres and the telomerase enzyme. It is possible that the drug can damage DNA at specific regions, e.g. within the telomeres. Because telomeres are not transcribed, they will not be repaired as effectively as the transcriptionally active part of chromosomes and this will make even low levels of telomere damage sufficient to cause senescence and cell death (Cohen \& Lippard, 2001). But we have recently shown that a conjugate of cisplatin with selenium could inhibit telomerase activity independently of its DNA-damaging effect (Błasiak et al., 2002). We hypothesized that the conjugate, like cisplatin itself, could form intrastrand adducts with guanine residues, G-Pt-G, in the DNA/RNA regions essential for the expression or maintenance of telomerase activity.

\section{H1 HISTONE CAN PREFERENTIALLY BIND TO CISPLATIN-MODIFIED DNA}

The linker histone $\mathrm{H} 1$ binds much more strongly to cisplatinated DNA than to 
transplatinated or unmodified DNA (Yaneva et al., 1997). $\mathrm{H} 1$ binds to cisplatin-damaged DNA with high affinity, about 20 -fold higher than HMG1. The data about binding of histone $\mathrm{H} 1$ to cisplatin-modified DNA are related to the earlier report on the preferential formation of the intrastrand crosslinks by cisplatin within the linker region of chromatin (Hayes \& Scovell, 1991). The DNase I cleavage pattern observed on cisplatin-modified chromatin and core particles indicates that there is very little distortion of the native helical twist of the modified DNA.

The higher affinity of cisplatin-modified DNA for the linker histone as compared with the proteins of the HMG1/2 group, led to the suggestion that this histone can be the most likely occupant of sites of DNA-cisplatin adducts in the cell. Interestingly, the linker, lysine-rich histones $\mathrm{H} 1$ and $\mathrm{H} 5$ share with the HMG1/2 proteins many DNA binding properties. Both classes of proteins bind preferentially to the linker DNA between adjacent nucleosomes in the bulk chromatin (van Holde, 1988). The HMG1 protein can also compete effectively with $\mathrm{H} 1$ for binding to Holliday junctions in vitro (Varga-Weisz et al., 1994). This observation, combined with the 10-fold higher abundance of the linker histone in the cell nucleus led to the conclusion that linker histone binding to cisplatin-damaged DNA sites might play a major role in the cytotoxicity of the drug (Zlatanova et al., 1998; van Holde, 1988).

\section{CONCLUDING REMARKS}

The anticancer activity of cisplatin is believed to arise from its binding to DNA, resulting in DNA-adducts. These adducts can be recognized by nuclear proteins, which may be part of the cellular repair systems or they may be DNA-binding proteins that recognize DNA sequences containing specific structural elements. Overexpression of some genes involved in nucleotide excision repair and de- fects in mismatch repair are associated with cisplatin resistance. The recognition of the major DNA-cisplatin adducts by HMG proteins may block their repair and contribute to the therapeutic action of cisplatin.

The clinical success of cisplatin for the treatment of cancer is clear but severe side effects and intrinsic or acquired resistance limit its application. In order to reduce the side effects and improve the effectiveness of cisplatin, a number of cisplatin analogues have been synthesized (Guo \& Sadler, 1999). The molecular mechanisms of action and protective strategies of the new platinum compounds are intensively investigated at present (Błasiak et al., 1999; Błasiak et al., 2000; Błasiak \& Kowalik, 2001). The results regarding the interaction of platinum compounds with telomeres and telomerase may open a new area in the investigation of platinum-based drugs.

\section{R E F E R E N C E S}

Aboussekhra A, Wood RD. (1994) Repair of ultraviolet light-damaged DNA by mammalian cells and Saccharomyces cerevisiae. Curr Opin Genet Dev.; 4: 212-20.

Aebi S, Kurdihaidar B, Gordon R, Cenni B, Zheng H, Fink D, Christen RD, Boland CR, Koi M, Fishel R, Howell SB. (1996) Loss of DNA mismatch repair in acquired resistance to cisplatin. Cancer Res.; 56: 3087-90.

Anthoney DA, McIlwrath AJ, Gallagher WM, Edlin AR, Brown R. (1996) Microsatellite instability, apoptosis and loss of p53 function in drug-resistant tumor cells. Cancer Res.; 56: $1374-81$.

Arioka H, Nishio K, Ishida T, Fukumoto H, Fukuoka K, Nomoto T, Kurokawa H, Yokote H, Abe S, Saijo N. (1999) Enhancement of cisplatin sensitivity in high mobility group 2 cDNA-transfected human lung cancer cells. Jpn J Cancer Res.; 90: 108-15.

Asai A, Kiyozuka Y, Yoshida R, Fujii T, Hioki K, Tsubura A. (1998) Telomere length, telomerase activity and telomerase RNA ex- 
pression in human esophageal cancer cells: correlation with cell proliferation, differentiation and chemosensitivity to anticancer drugs. Anticancer Res.; 18: 1465-72.

Bellon SF, Coleman JH, Lippard SJ. (1991) DNA unwinding produced by site-specific intrastrand cross-links of the antitumor drug cis-diamminedichloroplatinum(II). Biochemistry.; 30: 8026-35.

Błasiak J, Kowalik J. (2001) Protective action of vitamin $\mathrm{C}$ against DNA damage induced by selenium-cisplatin conjugate. Acta Biochim Polon.; 48: 233-40.

Błasiak J, Kadłubek M, Kowalik J, Romanowicz-Makowska H, Pertyński T. (2002) Inhibition of telomerase activity in endometrial cancer cells by selenium-cisplatin conjugate despite suppression of its DNA-damaging activity by sodium ascorbate. Teratog Carcinog Mutagen.; 22: 73-82.

Błasiak J, Kowalik J, Małecka-Panas E, Drzewoski J, Wojewódzka M. (2000) DNA damage and repair in human lymphocytes exposed to three anticancer platinum drug. Teratog Carcinog Mutagen.; 20: 119-31.

Błasiak J, Kowalik J, Trzeciak A, Wojewódzka M. (1999) Cytotoxicity and DNA damage and repair in human lymphocytes exposed to three anticancer platinum drugs. Neoplasma.; 46: $61-3$.

Brown SJ, Chow CS, Lippard SJ. (1994) Platinum-based anticancer drugs. In Encyclopaedia of inorganic chemistry. King RB. ed, vol 6, pp 3305-15. John Wiley, Sons, Chichester.

Brown SJ, Kellett PJ, Lippard SJ. (1993) Ixr1, a yeast protein that binds to platinated DNA and confers sensitivity to cisplatin. Science.; 261: $603-5$.

Burger AM, Double JA, Newell DR. (1997) Inhibition of telomerase activity by cisplatin in human testicular cancer cells. Eur J Cancer.; 33: 638-44.

Bustin M, Reeves R. (1996) High-mobility-group chromosomal proteins: architectural components that facilitate chromatin function. Prog Nucleic Acid Res Mol Biol.; 54: 35-100.
Chaney SG, Sancar A. (1996) DNA repair: enzymatic mechanisms and relevance to drug response. J Natl Cancer Inst.; 88: 1346-60.

Chao CC-K, Huang S-L, Lee Y-L, Lin-Chao S. (1991) Identification of inducible damage-recognition proteins that are overexpressed in HeLa cells resistant to cis-diamminedichloroplatinum(II). Biochem J.; 277: 875-8.

Chao JC, Wan XS, Engelsberg BN, Rothblum LI, Billings PC. (1996) Intracellular distribution of HMG1, HMG2 and UBF change following treatment with cisplatin. Biochim Biophys Acta.; 1307: 213-9.

Chen G, Hutter KJ, Zeller WJ. (1995) Positive correlation between cellular glutathione and acquired cisplatin resistance in human ovarian cancer cells. Cell Biol Toxicol.; 11: 273-81.

Chow SC, Barnes CM, Lippard SJ. (1995) A single HMG domain in high-mobility group 1 protein binds to DNAs as small as 20 base pairs containing the major cisplatin adduct. Biochemistry.; 34: 2956-64.

Chu G. (1994) Cellular responses to cisplatin. $J$ Biol Chem.; 269: 787-90.

Cleaver JE, Charles WC, McDowell ML, Sadinski WJ, Mitchell DL. (1995) Overexpression of the XPA repair gene increases resistance to ultraviolet radiation in human cells by selective repair of DNA damage. Cancer Res.; 55: 6152-60.

Clubb BH, Locke M. (1998) Peripheral nuclear matrix actin forms perinuclear shells. $J$ Cell Biochem.; 70: 240-51.

Cohen SM, Lippard SJ. (2001) Cisplatin: from DNA damage to cancer chemotherapy. Prog Nucleic Acid Res Mol Biol.; 67: 93-130.

Comess KM, Burstyn JN, Essigmann JM, Lippard SJ. (1992) Replication inhibition and translesion synthesis on templates containing site-specifically placed cis-diamminedichloroplatinum(II) DNA adducts. Biochemistry.; 31: 3975-90.

Corda Y, Job C, Anin MF, Leng M, Job D. (1991) Transcription by eucaryotic and procaryotic RNA polymerases of DNA modified at a 
$d(G G)$ or a $d(A G)$ site by the antitumor drug cis-diamminedichloroplatinum(II).

Biochemistry.; 30: 222-30.

Coste F, Malinge J-M, Serre L, Shepard W, Roth M, Leng M, Zelwer C. (1999) Crystal structure of a double-stranded DNA containing a cisplatin interstrand cross-link at $1.63 \AA$ resolution: hydration at the platinated site. $\mathrm{Nu}$ cleic Acids Res.; 27: 1837-46.

Dabholkar M, Vionnet J, Bostick-Bruton F, Yu JJ, Reed E. (1994) Messenger RNA levels of XPA and ERCC1 in ovarian cancer tissue correlate with response to platinum-based chemotherapy. J Clin Invest.; 94: 703-8.

de Lange T. (1992) Human telomeres are attached to the nuclear matrix. EMBO J.; 11: $717-24$

Dempke W, Voigt W, Grothey A, Hill BT, Schmoll HJ. (2000) Cisplatin resistance and oncogenes - a review. Anticancer Drugs.; 11: 225-36.

Dijt FJ, Fichtinger-Schepman AM, Berends F, Reedijk J. (1988) Formation and repair of cisplatin-induced adducts to DNA in cultured normal and repair-deficient human fibroblast. Cancer Res.; 48: 6058-62.

Duckett DR, Drummond JT, Murchie AIH, Reardon JT, Sancar A, Lilley DM, Modrich P. (1996) Human MutS $\alpha$ recognizes damaged DNA base pairs containing $\mathrm{O}^{6}$-methylguanine, $\mathrm{O}^{4}$-methylthymine, or the cisplatin-d(GpG) adduct. Proc Natl Acad Sci U S A.; 93: 6443-7.

Farid RS, Bianchi ME, Falciola L, Engelsberg BN, Billings PC. (1996) Differential binding of HMG1, HMG2 and a single HMG domain to cisplatin-damaged DNA. Toxicol Appl Pharmacol.; 141: 532-9.

Ferraro A, Grandi P, Eufemi M, Altieri F, Turano C. (1992) Crosslinking of nuclear proteins to DNA by cis-diamminedichloroplatinum in intact cells. FEBS Lett.; 307: 383-5.

Fichtinger-Schepman AMJ, van der Veer JL, den Hertog JHJ, Lohman PHM, Reedijk J. (1985) Adducts of the antitumor drug cis-diamminedichloroplatinum(II) with DNA: formation, identification and quantitation. Biochemistry.; 24: $707-13$.

Fink D, Nebel S, Aebi S, Zheng H, Cenni B, Nehmé A, Christen RD, Howell SB. (1996) The role of DNA mismatch repair in platinum drug resistance. Cancer Res.; 56: 4881-6.

Fraval HNA, Rawlings CJ, Roberts JJ. (1978) Increased sensitivity of UV-repair-deficient human cells to DNA bound platinum products, which unlike thymine dimers are not recognized by an endonuclease extracted from Micrococcus luteus. Mutat Res.; 51: 121-32.

Grosschedl R, Giese K, Pagel J. (1994) HMG domain proteins: architectural elements in the assembly of nucleoprotein structures. Trends Genet.; 10: 94-100.

Guo Z, Sadler PJ. (1999) Metals in medicine. Angew Chem Int Ed.; 38: 1512-31.

Hayes J, Scovell WM. (1991) Cis-diamminedichloroplatinum(II) modified chromatin and nucleosomal core particle. Biochim Biophys Acta.; 1089: 377-85.

Heminger K, Hartson SD, Rogers J, Matts RL. (1997) Cisplatin inhibits protein synthesis in rabbit reticulocyte lysate by causing an arrest in elongation. Arch Biochem Biophys.; 344: $200-7$.

Hoffmann J-S, Pillaire M-J, Garcia-Estefania D, Lapalu S, Villani G. (1996) In vitro bypass replication of the cisplatin-d(GpG) lesion by calf thymus DNA polymerase and human immunodeficiency virus type I reverse transcriptase is highly mutagenic. J Biol Chem.; 271: 15386-92.

Huang J-C, Zamble DB, Reardon JT, Lippard SJ, Sancar A. (1994) HMG-domain proteins specifically inhibit the repair of the major DNA adduct of the anticancer drug cisplatin by human excision nuclease. Proc Natl Acad Sci $U S$ A.; 91: 10394-8.

Hughes EN, Engelsberg BN, Billings PC. (1992) Purification of nuclear proteins that bind to cisplatin-damaged DNA. J Biol Chem.; 267: 13520-7. 
Ishibashi T, Lippard SJ. (1998) Telomere loss in cells treated with cisplatin. Proc Natl Acad Sci U S A.; 95: 4219-23.

Jantzen H, Admon A, Bell SP, Tijan R. (1990) Nucleolar transcription factor hUBF contains a DNA-binding motif with homology to HMG proteins. Nature.; 344: 830-6.

Jordan P, Carmo-Fonseca M. (1998) Cisplatin inhibits synthesis of ribosomal RNA in vivo. Nucleic Acids Res.; 26: 2831-6.

Jordan P, Carmo-Fonseca M. (2000) Molecular mechanisms involved in cisplatin cytotoxicity. Cell Mol Life Sci.; 57: 1229-35.

Kartalou M, Essigmann JM. (2001) Recognition of cisplatin adducts by cellular proteins. Mutat Res.; 478: 1-21.

Kartalou M, Samson LD, Essigmann JM. (2000) Cisplatin adducts inhibit $1, N^{6}$-ethenoadenine repair by interacting with the human 3-methyladenine DNA glycosylase. Biochemistry.; 39: 8032-8.

Larminat F, Bohr VA. (1994) Role of the human ERCC1 gene in gene-specific repair of cisplatin-induced DNA damage. Nucleic Acids Res.; 22: 3005-10.

Li Q, Yu JJ, Mu C, Yunmbam MK, Slavsky D, Cross CL, Bostick-Bruton F, Reed E. (2000) Association between the level of ERCC1 expression and the repair of cisplatin-induced DNA damage in human ovarian cancer cells. Anticancer Res.; 20: 645-52.

Lin X, Kim HK, Howell SB. (1999) The role of DNA mismatch repair in cisplatin mutageneticity. J Inorg Biochem.; 77: 89-93.

Locker D, Decoville M, Maurizot JC, Bianchi ME, Leng M. (1995) Interaction between cisplatin-modified DNA and the HMG boxes of HMG 1: DNase I footprinting and circular dichroism. J Mol Biol.; 246: 243-7.

Loehrer PJ, Einhorn LH. (1984) Diagnosis and treatment: cisplatin. Ann Int Med.; 100: 704-13.

Malinge J-M, Giraud-Panis M-J, Leng M. (1999) Interstrand cross-links of cisplatin induce striking distortions in DNA. J Inorg Biochem.; 77: 23-9.
Malinge J-M, Pérez C, Leng M. (1994) Base sequence-independent distorsions induced by interstrand cross-links in cis-diamminedichloroplatinum (II)-modified DNA. Nucleic Acids Res.; 22: 3834-9.

McA'Nulty MM, Whitehead JP, Lippard SJ. (1996) Binding of Ixr1, a yeast HMG-domian protein, to cisplatin-DNA adducts in vitro and in vivo. Biochemistry.; 35: 6089-99.

Metzger R, Leichman CG, Danenberg KD, Danenberg PV, Leichman L. (1998) ERCC1 mRNA levels complement thymidylate synthase mRNA levels in predicting response and survival for gastric cancer patients receiving combination cisplatin and fluorouracil chemotherapy. J Clin Oncol.; 16: 309-16.

Miao F, Bouziane M, Dammann R, Masutani Ch, Hanaoka F, Pfeifer G, O'Connor TR. (2000) 3-Methyladenine-DNA glycosylase (MPG protein) interacts with human RAD23 proteins. J Biol Chem.; 275: 28433-8.

Miller CA, Cohen MD, Costa M. (1991) Complexing of actin and other nuclear proteins to DNA by cis-diamminedichloroplatinum(II) and chromium compounds. Carcinogenesis.; 12: 269-76.

Modrich P. (1997) Strand-specific mismatch repair in mammalian cells. $J$ Biol Chem.; 272: 24727-30.

Moggs JG, Szymkowski DE, Yamada M, Karran P, Wood RD. (1997) Differential human nucleotide excision repair of paired and mispaired cisplatin-DNA adducts. Nucleic Acids Res.; 25: 480-90.

Nakayasu H, Ueda K. (1985) Association of rapidly-labelled RNAs with actin in nuclear matrix from mouse L5178Y cells. Exp Cell Res.; 160: $319-30$.

Nardozza TA, Quigley MM, Getzenberg RH. (1996) Association of transcription factors with the nuclear matrix. J Cell Biochem.; 61: 467-77.

Nguyen E, Besombes D, Debey P. (1998) Immunofluorescent localization of actin in re- 
lation to transcription sites in mouse pronuclei. Mol Reprod Dev.; 50: 263-72.

Niedner H, Christen R, Lin X, Kondo A, Howell SB. (2001) Identification of genes that mediate sensitivity to cisplatin. Mol Pharmacol.; 60: $1153-60$.

Nishio M, Arioka H, Nishio K, Kubota N, Heike Y, Ohata M, Saijo N. (1994) Overexpression of cisplatin-inducible proteins that are recognized by anti-HMG antibody in cisplatin-resistant human lung cancer cell lines. Cell Pharmacol.; 1: 251-5.

Ohndorf U-M, Whitehead JP, Raju NL, Lippard SJ. (1997) Binding of tsHMG, a mouse testis-specific HMG-domain protein, to cisplatin-DNA adducts. Biochemistry.; 36: 14807-15.

Ohndorf U-M, Rould MA, He Q, Pabo CO, Lippard SJ. (1999) Basis for recognition of cisplatin-modified DNA by high-mobilitygroup proteins. Nature.; 399: 708-12.

Oliński R, Wedrychowski A, Schmidt WN, Briggs RC, Hnilica LS. (1987) In vivo DNA-protein cross-linking by cis- and trans-diamminedichloroplatinum(II). Cancer Res.; 47: 201-5.

Parker RJ, Eastman A, Bostick-Bruton F, Reed E. (1991) Acquired cisplatin resistance in human ovarian cancer cells is associated with enhanced DNA repair of cisplatin-DNA lesions and reduced drug accumulation. J Clin Invest.; 87: 773-7.

Pil PM, Lippard SJ. (1992) Specific binding of chromosomal protein HMG1 to DNA damaged by the anticancer drug cisplatin. Science.; 256: 234-7.

Pontiggia A, Rimini R, Harley VR, Goodfellow PN, Lovell-Badge R, Bianchi ME. (1994) Sex-reversing mutations affect the architecture of SRY-DNA complexes. EMBO J.; 13: 6115-24.

Roberge M, Gasser SM. (1992) DNA loops: structural and functional properties of scaffold-attached regions. Mol Microbiol.; 6: 419-23.

Rosenberg B, Van Camp L, Grimley EB, Thomson AJ. (1967) The inhibition of growth or cell division in Escherichia coli by different ionic species of platinum(IV) complexes. $J$ Biol Chem.; 242: 1347-52.

Rosenberg B, Van Camp L, Krigas T. (1965) Inhibition of cell division by electrolysis products from a platinum electrode. Nature.; 205: 698-9.

Sahlas DJ, Milankov K, Park PC, De Boni U. (1993) Distribution of snRNPs, splicing factor SC-35 and actin in interphase nuclei: immunocytochemical evidence for differential distribution during changes in functional states. J Cell Sci.; 105: 347-57.

Sato P, Rosenberg J. (1993) Cisplatin inhibition of translation. Curr Topics Mol Pharmacol.; 1: 75-96.

Slupianek A, Hoser G, Majsterek I, Bronisz A, Malecki M, Blasiak J, Fishel R, Skorski T. (2002) Fusion tyrosine kinases induce resistance by stimulation of homology-dependent recombination repair, prolongation of $\mathrm{G}_{2} / \mathrm{M}$ phase, and protection from apoptosis. $\mathrm{Mol}$ Cell Biol.; 22: 4189-201.

Suo Z, Lippard SJ, Johnson KA. (1999) Single $\mathrm{d}(\mathrm{GpG})$ cis-diammineplatinum(II) adduct-induced inhibition of DNA polymerization. Biochemistry.; 38: 715-26.

Szymkowski DE, Yarema K, Essigmann JM, Lippard SJ, Wood RD. (1992) An intrastrand $\mathrm{d}(\mathrm{GpG})$ platinum crosslink in duplex M13 DNA is refractory to repair by human cell extracts. Proc Natl Acad Sci U S A.; 89: 10772-6.

Takahara PM, Frederick CA, Lippard SJ. (1996) Crystal structure of the anticancer drug cisplatin bound to duplex DNA. J Am Chem Soc.; 118: 12309-21.

Treiber DK, Zhai XQ, Jantzen HM, Essigmann JM. (1994) Cisplatin-DNA adducts are molecular decoys for the ribosomal RNA transciption factor hUBF (human upstream binding factor). Proc Natl Acad Sci US A.; 91: $5672-6$.

Trimmer EE, Essigmann JM. (1999) Cisplatin. Essays Biochem.; 34: 191-211.

Trimmer EE, Zamble DB, Lippard SJ, Essigmann JM. (1998) Human tes- 
tis-determining factor SRY binds to the major DNA adducts of cisplatin and a putative target sequence with comparable affinities. Biochemistry.; 37: 352-62.

Turchi JJ, Henkels KM, Hermanson IL, Patrick SM. (1999) Interactions of mammalian proteins with cisplatin-damaged DNA. J Inorg Biochem.; 77: 83-7.

Turchi JJ, Li M, Henkels KM. (1996) Cisplatin-DNA binding specificity of calf high-mobility group 1 protein. Biochemistry.; 35: 2992-3000.

Vaisman A, Varchenko M, Umar A, Kunkel TA, Risinger JI, Barrett JC, Hamilton TC, Chaney SG. (1998) The role of hMLH1, hMSH3, and hMSH6 defects in cisplatin and oxaliplatin resistance: correlation with replicative bypass of platinum-DNA adducts. Cancer Res.; 58: 3579-85.

van Holde KE. (1988) Chromatin. SpringerVerlag, New York.

van Wijnen AJ, Bidwell JP, Fey EG, Penman S, Lian JB, Stein JL, Stein GS. (1993) Nuclear matrix association of multiple sequence-specific DNA binding activities related to SP-1, ATF, CCAAT, E/EBP, OCT-1 and AP-1. Biochemistry.; 32: 8397-402.

Varga-Weisz P, van Holde KE, Zlatanova J. (1994) Competition between linker histones and HMG1 for binding to four-way junction DNA: implications for transcription. Biochem Biophys Res Commun.; 203: 1904-11.

Vichi P, Coin F, Renaud J-P, Vermeulen W, Hoeijmakers JHJ, Moras D, Egly J-M. (1997) Cisplatin- and UV-damaged DNA lure the basal transcription factor TFII/TBP. EMBO J.; 16: 7444-56.
Wood RD. (1996) DNA repair in Eukaryotes. Annu Rev Biochem.; 65: 135-67.

Woźniak K, Walter Z. (2002) Immunospecific protein of $34.5 \mathrm{kDa}$ from DNA-protein cross-links induced by cis- and trans-diamminedichloroplatinum. Cell Biol Int.; 26: 495-503.

Yamada M, O'Regan E, Brown R, Karran P. (1997) Selective recognition of a cisplatin-DNA adduct by human mismatch repair proteins. Nucleic Acids Res.; 25: 491-5.

Yaneva J, Leuba SH, van Holde K, Zlatanova J. (1997) The major chromatin protein histone H1 binds preferentially to cis-platinum-damaged DNA. Proc Natl Acad Sci U S A.; 94: 13448-51.

Yu JJ, Dabholkar M, Bennett WP, Welsh JA, Mu C, Bostick-Bruton F, Reed E. (1996) Platinum-sensitive and platinum-resistant ovarian cancer tissues show differences in the relationships between mRNA levels of p53, ERCC1 and XPA. Int J Oncol.; 8: 313-7.

Zamble DB, Mu D, Reardon JT, Sancar A, Lippard SJ. (1996) Repair of cisplatin-DNA adducts by the mammalian excision nuclease. Biochemistry.; 35: 10004-13.

Zeng H, Wang K, Wang B, Zhang Y. (1996) Studies on the thermokinetic characterisation of actin polymerization and the effect of cisplatin. Int J Biol Macromol.; 18: 161-6.

Zlatanova J, Yaneva J, Leuba SH. (1998) Proteins that specifically recognize cisplatin-damaged DNA: a clue to anticancer activity of cisplatin. FASEB J.; 12: 791-9. 